\title{
Seed germination and performance of sunflower seedlings submitted to produced water
}

\section{Germinação de sementes e desempenho de plântulas de girassol submetidas à água produzida}

\author{
Claudia Antonia Vieira Rossetto ${ }^{1}$ (D), Leonardo Oliveira Medici ${ }^{(\mathbb{D})}$, Camila Santos Barros de Morais ${ }^{3}$ (D), \\ Rosária da Costa Faria Martins ${ }^{1}$ (D), Daniel Fonseca de Carvalho ${ }^{4 *}$ (iD)
}

\author{
'Universidade Federal Rural do Rio de Janeiro/UFRRJ, Departamento de Fitotecnia, Instituto de Agronomia, Seropédica, RJ, Brasil \\ ${ }^{2}$ Universidade Federal Rural do Rio de Janeiro/UFRRJ, Departamento de Ciências Fisiológicas, Instituto de Ciências Biológicas e da Saúde, \\ Seropédica, RJ, Brasil \\ Instituto Federal de Educação, Ciência e Tecnologia do Ceará/IFCE, Tianguá, CE, Brasil \\ ${ }^{4}$ Universidade Federal Rural do Rio de Janeiro/UFRRJ, Departamento de Engenharia, Instituto de Tecnologia, Seropédica, RJ, Brasil \\ ${ }^{*}$ Corresponding author: daniel.fonseca.carvalho@gmail.com \\ Received in May 13, 2021 and approved in June 9, 2021
}

\begin{abstract}
The use of produced water becomes an option in the irrigation of non-food crops with potential for biofuel production. However, its effects on different stages of plant development and mainly on seed germination should be known. The study was conducted to evaluate the performance of sunflower seedlings subjected to different types of produced water. An experimental design in a factorial scheme was adopted to evaluate 3 cultivars (Catissol 01, Embrapa 122 and IAC laramã) and 6 types of water (distilled water - control, public-supply water, water resulting from the water and oil separation process - WOS, filtration in sand filter - SAF, filtration in sand + charcoal filter - SCF, and filtration in sand + osmosis filter - SOF). In addition, the substrate was moistened with polyethylene glycol (PEG) solutions, simulating the osmotic potentials of the evaluated waters, and a sensitivity test was conducted with lettuce seeds under conditions similar to those adopted for sunflower. The cv. Catissol showed higher percentages of germination and vigor of seedlings, regardless of the water used. There was a trend of reduction in germination and vigor of seedlings with the use of produced water treated with the WOS, SAF and SCF systems. All water potentials simulated by PEG solutions reduced the germination and vigor of lettuce seeds, and the effect was more pronounced for the WOS system. SOF was the only one capable of making the produced water non-toxic to sunflower seeds and lettuce seedlings.
\end{abstract}

Index terms: Helianthus annuus L.; vigor; water restriction; phytotoxicity; polyethylene glycol.

\section{RESUMO}

O uso de água produzida torna-se opção na irrigação de culturas não alimentícias e que apresentam potencial para a produção de biocombustível. Contudo, seus efeitos devem ser conhecidos em diferentes fases de desenvolvimento das plantas e, principalmente, na germinação das sementes. O trabalho foi desenvolvido visando avaliar o desempenho de plântulas de girassol submetidas a diferentes tipos de água produzida. Adotando delineamento experimental em esquema fatorial, foram avaliados 3 cultivares (Catissol 01, Embrapa 122 e IAC laramã) e 6 tipos de água (água destilada - testemunha, água de abastecimento, água resultante do processo de separação água e óleo - WOS, da filtragem em filtro de areia - SAF, da filtragem em filtro de areia e carvão - SCF, e da filtragem em filtro de areia + osmose - SOF). Também foi usado o umedecimento do substrato com soluções de polietilenoglicol, simulando os potenciais osmóticos das águas avaliadas, e realizado o teste de sensibilidade com sementes de alface sob condições similares às adotadas para girassol. A cv. Catissol apresentou maiores porcentagens de germinação e vigor de plântulas, independente da água utilizada. Houve tendência de redução da germinação e do vigor das plântulas com o uso da água produzida tratada com os sistemas WOS, SAF e SCF. Todos os potenciais hídricos simulados por soluções de PEG reduziram a germinação e vigor das sementes de alface, sendo esta mais acentuada para o sistema WOS. A SOF foi a única capaz de tornar a água produzida não tóxica para as sementes de girassol e plântulas de alface.

Termos para indexação: Helianthus annuus L.; vigor; restrição hídrica; fitotoxidez; polietilenoglicol. 


\section{INTRODUCTION}

Sunflower (Helianthus annuus L.) is an annual eudicotyledonous plant originating in North America (Zobiole et al., 2010). This species is among those with highest potential for biofuel production and is an option to be used in crop rotation or succession systems (Nobre et al., 2010). It has ornamental potential (Oliveira et al., 2017) and is used in human and animal feeding (Tarsitano et al., 2016), which makes it a crop of high economic interest.

Using high-quality seeds is fundamental for successful production and, for their germination, the combination of a number of favorable environmental factors is essential. In this stage, the soaking process is considered critical (Albuquerque; Carvalho, 2003) and water availability in the substrate is a decisive factor because water deficit conditions reduce the emergence speed and development of seedlings (Dousseau et al., 2011; Masetto; Ribeiro; Rezende, 2013).

Water supply is the most limiting factor in production of agricultural crops particularly in arid regions (Hatamian et al., 2019). In this regions, the use of wastewater is an alternative to solve problems arising from water scarcity and from the priority use of drinking water (Oliveira et al., 2017). Within this context, "produced water" (Al-Ghouti et al., 2019), generated in large volumes during the extraction, processing and refinement of hydrocarbons by the oil and gas industry (OGI) (Echchelh; Hess; Sakrabani, 2018), may be an option to be used in irrigated crops. In the case of onshore exploration areas, the management of oil produced water is a huge challenge for oil companies, whose common alternatives to its destination are disposal, injection and reuse (Motta et al., 2013). However, depending on the treatment conditions of the produced water, it can be reused in irrigation (Echchelh; Hess; Sakrabani, 2018), gaining greater importance mainly for crops located in the vicinity of oil and gas exploration and extraction facilities and in arid regions, where water is scarce (Guerra; Dahm; Dundorf, 2011; Sousa et al., 2016). However, attention should be paid to the quality of this water, as its use can have significant effect on soil fertility, microbial activity and on plant growth and productivity (Ahmadi; Souri, 2020; Souri; Hatamian, 2019).

The use of produced water in the irrigation of non-food crops, after different treatments, is a practice that has been studied in Brazil. For successive cycles of grain production, Meneses et al. (2017) evaluated the effect of treated produced water on the biological properties of soil cultivated with the castor bean and the sunflower. The microbiological activity and soil organic carbon were sensitive to the irrigation of sunflower plants with oilfield produced water, while in the castor bean crop, that irrigation affected soil basal respiration. Produced water irrigation affected nutrient accumulation in the sunflower plants (Sousa et al., 2016). The irrigation with reverse osmosis-treated produced water promoted the accumulation of $\mathrm{Ca}, \mathrm{Na}, \mathrm{N}, \mathrm{P}$, and $\mathrm{Mg}$, while in areas irrigated with filtered produced water there was accumulation of $\mathrm{Na}$ in both roots and shoots, and biomass and seed production were negatively affected.

In addition to the soil and plants, it is important to evaluate the use of production water on the germination process of seeds. The effects observed in this initial stage of seedling performance can be elucidative for analyses of plant performance in the field, and may be indicated as an efficient methodology to estimate the physiological effects in subsequent stages, that is, in the development of plants exposed to various crop managements, such as irrigation with this type of wastewater.

Thus, the present study aimed to evaluate the germination of seeds and performance of seedlings of different sunflower cultivars subjected to different osmotic potentials in the substrate promoted by different types of produced water.

\section{MATERIAL AND METHODS}

\section{Seed germination and seedling performance}

The activities were carried out at the Seed Analysis Laboratory of the Plant Science Department of the Federal Rural University of Rio de Janeiro, in Seropédica, RJ, Brazil. The experiment was conducted using three lots of sunflower (Helianthus annuus L.) seeds with pericarp (achenes) of the cultivars Catissol 01, Embrapa 122 and IAC Iaramã, with potential for biofuel production, respectively acquired from the Piraí Sementes company, Embrapa Dourados and Agronomic Institute of Campinas.

The seeds were initially subjected to the determination of moisture content and then, for evaluating seedling performance, to the germination test according to the methodologies described in Brasil (2009), adapting the moistening of the germination substrate with produced water. For the moisture content test, conducted after standardization so as not to interfere in biological responses, four subsamples of 50 seeds of each cultivar were used, using the oven method at $105 \pm 3{ }^{\circ} \mathrm{C}$ for $24 \mathrm{~h}$.

The experimental design adopted for the seed germination test was completely randomized in a double 
factorial scheme ( 3 cultivars $x 6$ types of water), with four replicates. The types of water were distilled water (control) (DIST), the public-supply water from the oil extraction site (PSW) located in the state of Rio Grande do Norte (Brazil), and the produced water resulting from the water and oil separation process (WOS); filtration in sand filter (SAF); filtration in sand + charcoal filter (SCF); filtration in sand + osmosis filter (SOF). Except for distilled water, the other ones remained frozen until the beginning of the work. At the time of use, the waters were removed from the freezer $24 \mathrm{~h}$ before being used and thawed at room temperature (without control). Some chemical parameters of produced water are shown in Table 1.

Table 1: Chemical parameters of produced water.

\begin{tabular}{cc}
\hline Parameters & Values $\left(\mathrm{mg} \mathrm{L}^{-1}\right)$ \\
\hline Total organic carbon & 25.5 \\
Dissolved iron & 0.0165 \\
Total phosphorus & 0.015 \\
Ammoniacal nitrogen & 1.15 \\
Total zinc & 0.054 \\
\hline
\end{tabular}

For the germination test, four subsamples of 50 seeds were placed to germinate in Germitest ${ }^{\circledR}$ paper substrate moistened with six types of water, in the proportion of 2 times its dry weight, and then kept in germinator at $20-30{ }^{\circ} \mathrm{C}$, in the absence of light. The evaluations were performed four and ten days after the test was installed, considering as normal seedlings those with length greater than $4.0 \mathrm{~cm}$ and all structures developed, and as deformed abnormal seedlings those with weak development. Non-germinated seeds were considered as those that did not absorb water (hard), those that were dormant (absorbed water, but did not germinate) and also those that were dead (softened and with symptoms or signs caused by microorganisms).

Along with the germination test, the first count test, which is considered as indicative of seed vigor, was evaluated. For this, the percentage of normal seedlings was considered on the fourth day after installing the germination test (Nakagawa, 1999). The mass and length of the normal seedlings were also evaluated on the fourth day after the test was installed.

For the determination of length, the cotyledons of the normal seedlings were disregarded and the lengths of hypocotyl and primary root were measured using a ruler, with results expressed in centimeters per seedling. For the dry mass of seedlings, the parts of the plants (root and hypocotyl) were placed in paper bags, taken to a forced air circulation oven and kept at a temperature of $65^{\circ} \mathrm{C}$ until reaching constant weight, with results expressed in milligrams per seedling.

\section{Germination test under different osmotic potentials}

For this evaluation, the osmotic potential of each water used to moisten the substrate in the test was determined. For this, the electrical conductivity was determined using a portable conductivity meter. The obtained values were used to calculate the osmotic potential through the formula presented by Khaliq et al. (2012), where the osmotic potential (-MPa) is equal to electrical conductivity $\left(\mathrm{dS} \mathrm{m}^{-1}\right)$, multiplied by -0.036 .

In order to simulate the different osmotic potentials previously determined in the produced waters, polyethylene glycol 6000 solutions (PEG 6000) were prepared by adding $0,84.8,46.2,56.0,3.9$ and $29.1 \mathrm{~g}$ per liter of water aiming to reach the potentials shown in Table 2, respectively. These were obtained by the equation proposed by Michel and Kaufmam (1973) (Equation 1).

Table 2: Osmotic potential relative to distilled water, public-supply water and wastewater.

\begin{tabular}{ccccccc}
\hline $\begin{array}{c}\text { Osmotic } \\
\text { potential } \\
\text { (MPa) }\end{array}$ & DIST & WOS & SAF & SCF & SOF & PSW \\
\cline { 2 - 6 } & 0.0 & -0.1 & -0.04 & -0.06 & -0.002 & -0.02 \\
\hline
\end{tabular}

DIST - distilled water; PSW - public-supply water; WOS - water and oil separation; SAF - sand filter; SCF - sand + charcoal filter; SOF - sand + osmosis filter.

$\psi_{\text {os }}=-\left(1.18 \times 10^{-2}\right) \cdot \mathrm{C}-\left(1.18 \times 10^{-4}\right) \cdot \mathrm{C}^{2}+\left(2.67 \times 10^{-4}\right)$.
C.T $+\left(8.39 \times 10^{-7}\right) \cdot \mathrm{C}^{2} . \mathrm{T}$

in which $\psi_{\text {os }}$ is the osmotic potential (-MPa), $\mathrm{C}$ is the concentration of PEG $6000\left(\mathrm{~g} \mathrm{~kg}^{-1} \mathrm{H}_{2} \mathrm{O}\right)$ and $\mathrm{T}$ is the temperature $\left({ }^{\circ} \mathrm{C}\right)$.

Then, the germination test was installed, adopting a completely randomized experimental design in a double factorial scheme ( 3 cultivars x 6 osmotic potentials), with four replicates. The six different osmotic potentials corresponded to the values obtained in the determination of the osmotic potential of the same waters evaluated in the previous test. The installation of the test and the evaluations performed followed the same methodology described above, with Germitest ${ }^{\circledR}$ paper sheets moistened with PEG solution and without solution (use of distilled water). 


\section{Sensitivity test in seeds of indicator species}

The sensitivity test was conducted with common seeds of lettuce, cv Elba, which was used as an indicator species. The experimental design used was completely randomized, with the same six types of water used in the germination tests described above, with four replicates. For this, four subsamples of 50 lettuce seeds were evaluated by the germination test using Germitest ${ }^{\circledR}$ paper substrate moistened with distilled water, public-supply water and with produced water (WOS; filtration in sand filter; filtration in sand + charcoal filter; and filtration in sand + osmosis filter), in the proportion of 2 times its dry weight inside plastic, Gerbox-type boxes. These were kept in germinator at $20^{\circ} \mathrm{C}$, under 12 hours of light and 12 hours of dark. The evaluations were performed four and seven days after the installation of the test (Brasil, 2009). Along with the germination test, the tests of first count of germination, length and dry mass of seedlings were performed according to the procedures described for sunflower seeds.

The germination test of lettuce seeds under different osmotic potentials was also carried out, adopting the same installation procedures and evaluations performed on sunflower seeds. The experimental design adopted was completely randomized, with six osmotic potentials simulated by PEG and referring to those determined in the different types of water, with four replicates.

\section{Statistical analysis}

The data were subjected to analysis of variance and, for this, the normality and homogeneity of the error variances were first tested. Subsequently, some data collected in the sunflower germination test under different types of water needed to be transformed to arcsine root (x) (germination percentage, first count and non-germinated seeds) and transformed to root of $(x+1)$ (root length and hypocotyl length). In addition, some data collected in the germination test under different osmotic potentials needed to be transformed to arcsine root (x) (germination percentage, first count and non-germinated seeds) and transformed to root $(\mathrm{x}+1)$ (root length and hypocotyl length). Then, with the assumptions met, the $\mathrm{F}$ test was applied at 5\% probability level. For variables whose $\mathrm{F}$ test was significant, the means were compared by Tukey test at 5\% probability level (Zimmermann, 2004).

\section{RESULTS AND DISCUSSION}

The sunflower seeds of the cultivars Catissol 01, IAC Iaramã and Embrapa 122 had moisture contents of 5.5, 5.9 and 5.6\%, respectively. These values are important for the conservation and longevity of oilseeds during storage, reducing possible loss of viability due to lipid oxidation. Nobre et al. (2014) observed that moisture content between 4.2 and $5.3 \%$ did not interfere with the viability of sunflower achenes.

The cultivar Catissol showed higher germination, regardless of the produced water used, while seeds of the cultivar Embrapa showed lower germination mainly due to the higher percentage of non-germinated seeds and high percentage of abnormal seedlings, that is, with lower development (Table 3). According to Saux et al. (2020), the response of sunflower genotypes to stresses, such as water restriction, is closely correlated with the initial quality of the lot. Moreover, when the substrate was moistened with produced water treated by WOS, there was a drastic reduction in germination, i.e., in the formation of normal seedlings, regardless of the cultivar, although this value did not differ from that obtained using water from SCF. In the water from WOS, small drops of oil and/or other petroleum derivatives may remain, which will penetrate the seeds, killing the embryo or forming a physical barrier to the entry of oxygen and water, fundamental elements to trigger the germination process (Adam; Ducan, 2002).

The seeds of the cultivar ( $c v$.) Catissol showed greater vigor when evaluated by the percentage of normal seedlings in the first count of the germination test (Table 3). There was no difference among the different produced water mean values for percentage of normal seedlings in the first count. In addition, the $c v$. Catissol also had the highest values of vigor when evaluated based on hypocotyl length and root dry mass, although these did not differ from the values shown by the $c v$ s. IAC and Embrapa, respectively (Table 4).

Regardless of the cultivar, the treatment of produced water with WOS caused a drastic reduction in hypocotyl length, although the value did not differ from those of the SCF treatment and control, as well as a reduction in root dry mass, although the value did not differ from those of the SCF and SOF treatments (Table 4). These results were similar to those obtained for the percentage of normal seedlings (germination) (Table 3).

In the evaluation of vigor by the root length test, there was a marked reduction in the value of seeds of the $c v$. Catissol that were placed to germinate in substrate moistened with produced water treated by SCF, although the value did not differ from that obtained with water from WOS (Table 4). For the hypocotyl dry mass test, there was also a reduction in the value of seeds of the $c v$. Catissol when they were placed to germinate in substrate moistened with water from WOS, SCF and 
SOF treatments (Table 4). These results were similar to that obtained in the root length test (Table 4).

The values of osmotic potentials relative to the types of produced water ranged from -0.002 to $-0.1 \mathrm{MPa}$ (Table 2). According to Kaya et al. (2006), the osmotic potential of $-0.6 \mathrm{MPa}$ is considered critical for sunflower, because it causes reduction in its germination percentage. Thus, it can be observed that the osmotic potentials representative of the types of produced water were higher than $-0.6 \mathrm{MPa}$, possibly suggesting the non-interference in the germination and vigor of sunflower seeds only by water restriction. Inhibition of germination can occur due to salinity, which is due both to the osmotic effect, hindering the absorption of water by seeds, and to the ionic effect at toxic levels, providing inhibition of the synthesis and/or activity of hydrolytic enzymes necessary for germination (Rabbani et al., 2013).

The seeds of the $c v$. Catissol showed a reduction in germination percentage probably due to the increase in the percentage of abnormal seedlings, that is, with less development, and due to the vigor evaluated by the first germination count in substrates moistened with PEG solutions that simulated all osmotic potentials determined in the different types of wastewater (from -0.002 to $-0.1 \mathrm{MPa}$ ) (Table 5). However, the value found after the substrate was moistened with PEG solution, which simulates the potential of the produced water treated with SAF (osmotic potential of $-0.04 \mathrm{MPa}$ ), did not differ from the value found after moistening with distilled water (control). In addition, the most significant reduction occurred after moistening with PEG solution that simulates the osmotic potential of the produced water treated with SOF $(-0.002 \mathrm{MPa})$. When evaluating the germination percentage of sunflower seeds under water stress conditions, Lenzi et al. (1995) observed that the critical osmotic potential to inhibit $50 \%$ of the germination of this species was lower than $-0.3 \mathrm{MPa}$.

Table 3: Mean data of germination, normal seedlings in the first count of the germination test, abnormal seedlings and non-germinated seeds, of the three sunflower cultivars subjected to different types of water.

\begin{tabular}{|c|c|c|c|c|c|c|c|c|}
\hline \multirow{3}{*}{$\begin{array}{l}\text { Type of } \\
\text { water }\end{array}$} & \multicolumn{3}{|c|}{ Cultivar } & \multirow{3}{*}{ Mean } & \multicolumn{3}{|c|}{ Cultivar } & \multirow{3}{*}{ Mean } \\
\hline & Catissol & $\mathrm{IAC}$ & Embrapa & & Catissol & $\mathrm{IAC}$ & Embrapa & \\
\hline & \multicolumn{3}{|c|}{ Germination (\%) } & & \multicolumn{3}{|c|}{ First count (\%) } & \\
\hline DIST & 98 & 83 & 77 & $86 a$ & 90 & 67 & 50 & $69 a$ \\
\hline WOS & 95 & 80 & 62 & $79 d$ & 85 & 63 & 45 & $64 a$ \\
\hline SAF & 96 & 84 & 70 & $83 \mathrm{abc}$ & 84 & 59 & 49 & $64 \mathrm{a}$ \\
\hline SCF & 93 & 76 & 64 & $77 \mathrm{~cd}$ & 87 & 62 & 49 & $66 \mathrm{a}$ \\
\hline SOF & 98 & 82 & 73 & $84 a b$ & 93 & 63 & 47 & $68 \mathrm{a}$ \\
\hline PSW & 93 & 79 & 73 & $81 a b$ & 89 & 66 & 49 & $68 \mathrm{a}$ \\
\hline Means & $95 \mathrm{~A}$ & $80 \mathrm{~B}$ & $70 \mathrm{C}$ & & $88 \mathrm{~A}$ & $63 B$ & $48 C$ & \\
\hline \multirow[t]{2}{*}{ C.V. (\%) } & \multicolumn{3}{|c|}{4.84} & \multicolumn{5}{|c|}{5.58} \\
\hline & \multicolumn{3}{|c|}{ Abnormal seedlings (\%) } & Means & \multicolumn{3}{|c|}{ Non-germinated seeds (\%) } & Means \\
\hline DIST & $3 \mathrm{Bbc}$ & $12 \mathrm{Aab}$ & $14 \mathrm{Abc}$ & 9 & $0 \mathrm{Ca}$ & $5 \mathrm{Ba}$ & $10 \mathrm{Ac}$ & 5 \\
\hline WOS & $6 \mathrm{Cabc}$ & $13 \mathrm{Bab}$ & $21 \mathrm{Aab}$ & 13 & $0 \mathrm{Ca}$ & $7 \mathrm{Ba}$ & $17 \mathrm{Aa}$ & 8 \\
\hline SAF & $5 \mathrm{Babc}$ & $8 \mathrm{Bb}$ & $1 \mathrm{Aabc}$ & 10 & $0 \mathrm{Ca}$ & $9 \mathrm{Ba}$ & $13 \mathrm{Aabc}$ & 7 \\
\hline SCF & $8 \mathrm{Bab}$ & $19 \mathrm{Aa}$ & $24 \mathrm{Aa}$ & 17 & $0 \mathrm{Ca}$ & $6 \mathrm{Ba}$ & $13 \mathrm{Aabc}$ & 6 \\
\hline SOF & $3 \mathrm{Bc}$ & $13 \mathrm{Aab}$ & 16 Aabc & 11 & $0 \mathrm{Ca}$ & $6 \mathrm{Ba}$ & $11 \mathrm{Abc}$ & 6 \\
\hline PSW & $8 \mathrm{Ba}$ & $17 \mathrm{Aa}$ & $12 \mathrm{ABC}$ & 12 & $0 \mathrm{Ca}$ & $5 \mathrm{Ba}$ & 15 Aab & 7 \\
\hline Means & 5 & 13 & 17 & & 0 & 6 & 13 & \\
\hline C.V. (\%) & \multicolumn{3}{|c|}{13.56} & \multicolumn{5}{|c|}{15.58} \\
\hline
\end{tabular}

Means followed by the same letter, lowercase in the column for types of water and uppercase in the row for cultivars, do not differ from each other by Tukey test at $5 \%$ probability level. Means without any letters did not differ significantly from each other by Tukey test at 5\% probability level. DIST - distilled water; PSW - public-supply water; WOS - water and oil separation; SAF - sand filter; SCF - sand + charcoal filter; SOF - sand + osmosis filter. 
Table 4: Mean data of root length, hypocotyl length, root dry mass and hypocotyl dry mass of three sunflower cultivars subjected to different types of water.

\begin{tabular}{|c|c|c|c|c|c|c|c|c|}
\hline \multirow{3}{*}{$\begin{array}{l}\text { Type of } \\
\text { water }\end{array}$} & \multicolumn{4}{|c|}{ Cultivar } & \multicolumn{4}{|c|}{ Cultivar } \\
\hline & Catissol & $\mathrm{IAC}$ & Embrapa & Means & Catissol & IAC & Embrapa & Means \\
\hline & \multicolumn{4}{|c|}{ Root length (cm seedling ${ }^{-1}$ ) } & \multicolumn{4}{|c|}{ Hypocotyl length ( $\mathrm{cm}$ seedling ${ }^{-1}$ ) } \\
\hline DIST & $7.8 \mathrm{Aa}$ & 7.8Aa & 6.3Aa & 7.3 & 2.4 & 2.1 & 1.9 & $2.1 \mathrm{ab}$ \\
\hline WOS & $6.3 \mathrm{Abc}$ & $5.3 \mathrm{ABb}$ & $4.5 \mathrm{Bb}$ & 5.4 & 2.0 & 1.7 & 1.6 & $1.8 b$ \\
\hline SAF & 6.6Aabc & 6.5Aab & $5.9 \mathrm{Aa}$ & 6.4 & 2.2 & 2.7 & 1.9 & $2.3 a$ \\
\hline SCF & $5.9 A c$ & $6.1 \mathrm{Ab}$ & 5.4Aab & 5.8 & 2.0 & 2.0 & 1.9 & 2.0ab \\
\hline SOF & 7.6Aab & $5.7 \mathrm{Bb}$ & 5.7Bab & 6.3 & 2.6 & 2.1 & 2.1 & $2.2 \mathrm{a}$ \\
\hline PSW & 7.5Aab & 6.4Aab & 5.1Bab & 6.3 & 2.3 & 2.5 & 1.8 & $2.2 a$ \\
\hline Means & 6.9 & 6.3 & 5.5 & & $2.2 \mathrm{~A}$ & $2.2 \mathrm{~A}$ & $1.9 \mathrm{~B}$ & \\
\hline \multirow[t]{2}{*}{ C.V. (\%) } & & 4.52 & & & & 5.11 & & \\
\hline & \multicolumn{4}{|c|}{ Root dry mass (mg seedling ${ }^{-1}$ ) } & \multicolumn{4}{|c|}{ Hypocotyl dry mass (mg seedling ${ }^{-1}$ ) } \\
\hline DIST & 2.55 & 2.18 & 2.41 & $2.38 a$ & $6.10 \mathrm{Aa}$ & $5.26 \mathrm{Aa}$ & $5.22 \mathrm{Aa}$ & 5.52 \\
\hline WOS & 1.48 & 1.58 & 1.69 & $1.58 \mathrm{~d}$ & $4.11 \mathrm{Ab}$ & 3.77Ab & $3.56 \mathrm{Ac}$ & 3.81 \\
\hline SAF & 2.48 & 1.87 & 2.22 & 2.19ab & 5.71Aab & 4.85Aa & 4.98Aab & 5.18 \\
\hline SCF & 1.98 & 1.57 & 1.69 & $1.65 \mathrm{~cd}$ & $4.83 \mathrm{Ab}$ & $3.73 \mathrm{Ab}$ & $3.46 \mathrm{Bc}$ & 4.00 \\
\hline SOF & 1.80 & 1.72 & 1.72 & $1.75 \mathrm{bcd}$ & $4.78 \mathrm{Ab}$ & 4.35Aab & $3.94 \mathrm{Bbc}$ & 4.36 \\
\hline PSW & 2.26 & 1.81 & 2.07 & $2.05 \mathrm{ab}$ & 5.71Aab & $4.92 \mathrm{Aa}$ & 4.49Bab & 5.04 \\
\hline Means & $2.09 \mathrm{~A}$ & $1.78 \mathrm{~B}$ & $1.96 \mathrm{AB}$ & & 5.96 & 4.48 & 4.28 & \\
\hline C.V. (\%) & & 19.72 & & & & 9.88 & & \\
\hline
\end{tabular}

Means followed by the same letter, lowercase in the column for types of water and uppercase in the row for cultivars, do not differ from each other by Tukey test at $5 \%$ probability level. Means without any letters did not differ significantly from each other by Tukey test at 5\% probability level. DIST - distilled water; PSW - public-supply water; WOS - water and oil separation; SAF - sand filter; SCF - sand + charcoal filter; SOF - sand + osmosis filter.

For the $c v$. Catissol, there was also a marked reduction in the root length of seedlings after moistening the substrate with PEG solution that simulates the potential of produced water passed through the sand filter $(-0.04$ $\mathrm{MPa})$, sand + charcoal filter $(-0.06 \mathrm{MPa})$ and by WOS $(-0.1 \mathrm{MPa})$ (Table 6). There was also a reduction in the root dry mass of seedlings after moistening with water passed through sand filter (-0.04 MPa), although these values did not differ from the one obtained by the other treatments of water, except for public-supply water (-0.02 MPa) (Table 6). Although sunflower is considered a moderately tolerant crop to salinity, even so, there is a progressive reduction in growth, with an increase in the concentration of salts in the root medium.

Regardless of the produced water treatment, the $c v$. Catissol had the highest values of hypocotyl length and dry mass (Table 6). Regardless of the cultivar, there was a marked reduction in hypocotyl length after the seeds germinated in substrate moistened with PEG solution that simulates the osmotic potential of produced water after being passed through SOF (-0.04 MPa), although the value did not differ from the value obtained with SAF (-0.04 $\mathrm{MPa})$ and SCF (-0.06 MPa). There was also a reduction in hypocotyl dry mass after using water from WOS, although the value did not differ from the others (Table 6). When analyzing the effects of oilfield produced water on germination of sunflower seeds, Marques et al. (2015) found no significant variations in germination percentage, germination speed and seedling biomass.

For lettuce, there was a drastic reduction in germination when the seeds germinated in substrate moistened with produced water after passing through WOS, probably due to the increase in the percentages of abnormal seedlings, that is, with lower development, and non-germinated seeds. In addition, when the substrate was moistened with this type of water, there was an absence 
of normal seedlings in the first germination count (at four days after installation of the test) (Table 7), i.e., there was a reduction in germination speed. Franzin et al. (2004) indicate that the potential of $-0.3 \mathrm{MPa}$ is considered critical for lettuce seeds as it increases the percentage of abnormal seedlings.

In the evaluation of the germination test of lettuce seeds using substrate moistened with PEG solution, which simulated the produced water after passing through WOS (osmotic potential of -0.1 $\mathrm{MPa}$ ), a lower percentage of normal seedlings was also observed, probably due to the high percentage of deformed abnormal seedlings and non-germinated seeds (Table 8). Osmotic stress conditions do not let seeds achieve the optimum moisture levels required for imbibition, because the flow of water into the seed from its surroundings is restricted (Chadha et al., 2019), resulting in higher numbers of deformed abnormal seedlings and non-germinated seeds.

This same treatment led to a reduction in vigor, evaluated by the percentage of normal seedlings in the first count as well as in hypocotyl length and dry mass, although these values did not differ from those caused by other waters (Table 8 ). Thus, it is worth pointing out that, when the effect of the osmotic potential of $-0.1 \mathrm{MPa}$ simulated by PEG and referring to the osmotic potential of produced water treated by WOS was evaluated, it was found that this potential restricted but did not prevent the formation of normal lettuce seedlings at four days after germination, which occurred when lettuce seeds were placed to germinate in substrate moistened with produced water after passing through WOS (Table 7). This fact suggests a possible toxicity since this species is considered as an indicator.

Table 5: Mean data of germination, normal seedlings in the first count of the germination test, abnormal seedlings and non-germinated seeds of three sunflower cultivars, which were germinated in substrate moistened with solutions to simulate different osmotic potentials relative to different types of produced water.

\begin{tabular}{|c|c|c|c|c|c|c|c|c|}
\hline \multirow{3}{*}{$\begin{array}{l}\text { Type of } \\
\text { water }\end{array}$} & \multicolumn{4}{|c|}{ Cultivar } & \multicolumn{4}{|c|}{ Cultivar } \\
\hline & Catissol & $\mathrm{IAC}$ & Embrapa & Means & Catissol & IAC & Embrapa & Means \\
\hline & \multicolumn{4}{|c|}{ Germination (\%) } & \multicolumn{4}{|c|}{ First count (\%) } \\
\hline DIST & 98Aa & $83 \mathrm{Ba}$ & $76 \mathrm{Ca}$ & 85 & $90 \mathrm{Aa}$ & $63 \mathrm{Ba}$ & $49 \mathrm{Ca}$ & 67 \\
\hline WOS & 94Aab & $67 \mathrm{BC}$ & $60 \mathrm{Cc}$ & 73 & $80 A c$ & $43 B C$ & $25 C c$ & 49 \\
\hline SAF & 96Aa & $74 \mathrm{Bb}$ & $63 \mathrm{Cc}$ & 77 & 86Aab & $47 \mathrm{Bbc}$ & $33 \mathrm{Cb}$ & 55 \\
\hline SCF & 94Aab & $72 \mathrm{Bb}$ & $69 \mathrm{Cb}$ & 78 & $84 \mathrm{Abc}$ & $45 B C$ & $33 \mathrm{Cb}$ & 54 \\
\hline SOF & $91 \mathrm{Ab}$ & $79 B a$ & $72 \mathrm{Cab}$ & 80 & $84 \mathrm{Abc}$ & $52 \mathrm{Bb}$ & $36 \mathrm{Cb}$ & 57 \\
\hline PSW & 94Aab & $73 \mathrm{Bb}$ & $72 \mathrm{Cab}$ & 79 & $72 \mathrm{Ad}$ & $47 \mathrm{Bbc}$ & $35 \mathrm{Cb}$ & 51 \\
\hline Means & 94 & 74 & 68 & & 90 & 63 & 49 & \\
\hline \multirow[t]{2}{*}{ C.V. (\%) } & & 3.17 & & & & 3.37 & & \\
\hline & \multicolumn{4}{|c|}{ Abnormal seedlings (\%) } & \multicolumn{4}{|c|}{ Non-germinated seeds (\%) } \\
\hline DIST & $3 B C$ & $13 \mathrm{Ac}$ & $14 \mathrm{Ad}$ & 10 & 0 & 5 & 10 & $5 a$ \\
\hline WOS & $7 \mathrm{Bbc}$ & $31 \mathrm{Aa}$ & $35 \mathrm{Aa}$ & 24 & 0 & 2 & 6 & $3 a$ \\
\hline SAF & $4 \mathrm{Bbc}$ & 26Aab & 28Aab & 19 & 0 & 1 & 10 & $4 a$ \\
\hline SCF & 7Bab & $25 A a b$ & $24 A b c$ & 18 & 0 & 4 & 8 & $4 a$ \\
\hline SOF & $9 \mathrm{Ba}$ & $18 \mathrm{Abc}$ & $16 \mathrm{Acd}$ & 14 & 0 & 4 & 13 & $5 a$ \\
\hline PSW & 7Bab & 24Aab & 18Acd & 16 & 0 & 4 & 10 & $5 a$ \\
\hline Means & 6 & 23 & 22 & & OC & $3 B$ & $9 \mathrm{~A}$ & \\
\hline C.V. (\%) & & 10.19 & & & & 25.57 & & \\
\hline
\end{tabular}

Means followed by the same letter, lowercase in the column for osmotic potentials and uppercase in the row for cultivars, do not differ from each other by Tukey test at 5\% probability level. Means without any letters did not differ significantly from each other by Tukey test at 5\% probability level. DIST - distilled water; PSW - public-supply water; WOS - water and oil separation; SAF - sand filter; SCF - sand + charcoal filter; SOF - sand + osmosis filter. 
Table 6: Mean data of root length, hypocotyl length, root dry mass and hypocotyl dry mass of three sunflower cultivars, germinated in substrate moistened with solutions to simulateosmotic potentials relative to different types of produced water.

\begin{tabular}{|c|c|c|c|c|c|c|c|c|}
\hline \multirow{3}{*}{$\begin{array}{l}\text { Type of } \\
\text { water }\end{array}$} & \multicolumn{4}{|c|}{ Cultivar } & \multicolumn{4}{|c|}{ Cultivar } \\
\hline & Catissol & IAC & Embrapa & Means & Catissol & IAC & Embrapa & Means \\
\hline & \multicolumn{4}{|c|}{ Root length $\left(\mathrm{cm}\right.$ seedling ${ }^{-1}$ ) } & \multicolumn{4}{|c|}{ Hypocotyl length (cm seedling ${ }^{-1}$ ) } \\
\hline DIST & $6.8 \mathrm{Aa}$ & $4.4 \mathrm{Cb}$ & $5.2 \mathrm{Ba}$ & 5.5 & 2.0 & 1.6 & 1.7 & $1.8 \mathrm{a}$ \\
\hline WOS & $4.4 \mathrm{Ac}$ & 3.3Bd & $3.6 \mathrm{Bb}$ & 3.7 & 1.5 & 1.2 & 1.3 & $1.3 b$ \\
\hline SAF & $4.5 \mathrm{Ac}$ & $3.6 \mathrm{BC}$ & $3.6 \mathrm{Bb}$ & 3.9 & 1.3 & 1.0 & 1.3 & $1.2 \mathrm{bc}$ \\
\hline SCF & 4.1Ac & $2.8 \mathrm{Cd}$ & $3.4 \mathrm{Bb}$ & 3.4 & 1.2 & 1.2 & 1.1 & $1.1 \mathrm{bc}$ \\
\hline SOF & 6.3Aa & $5.2 \mathrm{Ba}$ & $3.7 \mathrm{Cb}$ & 5.0 & 1.0 & 0.9 & 1.1 & $1.0 \mathrm{c}$ \\
\hline PSW & $5.5 \mathrm{Ab}$ & 3.7Bc & 3.7Bb & 4.3 & 2.0 & 1.6 & 1.4 & $1.7 a$ \\
\hline Means & 5.2 & 3.8 & 3.9 & & $1.5 \mathrm{~A}$ & $1.2 \mathrm{~B}$ & $1.3 \mathrm{~B}$ & \\
\hline \multirow[t]{2}{*}{ C.V. (\%) } & & 2.62 & & & & 4.20 & & \\
\hline & \multicolumn{4}{|c|}{ Root dry mass (mg seedling ${ }^{-1}$ ) } & \multicolumn{4}{|c|}{ Hypocotyl dry mass (mg seedling-1 ${ }^{-1}$} \\
\hline DIST & 1.52Aab & $1.38 \mathrm{Aa}$ & $1.49 \mathrm{Aa}$ & 1.46 & 4.19 & 3.73 & 3.90 & $3.94 a$ \\
\hline WOS & $1.50 \mathrm{Aab}$ & 1.16Bab & $0.98 \mathrm{Bbc}$ & 1.22 & 2.26 & 2.07 & 2.03 & $2.12 \mathrm{c}$ \\
\hline SAF & $1.11 \mathrm{Ab}$ & $0.76 \mathrm{Ac}$ & $0.79 \mathrm{Abc}$ & 0.89 & 3.40 & 2.19 & 2.24 & $2.61 b c$ \\
\hline SCF & 1.35Aab & $1.23 \mathrm{Aab}$ & $0.71 \mathrm{Bc}$ & 1.10 & 3.60 & 2.51 & 2.28 & $2.79 b c$ \\
\hline SOF & 1.32Aab & $1.13 \mathrm{Abc}$ & 1.14Aab & 1.20 & 3.46 & 3.37 & 2.91 & $3.24 b$ \\
\hline PSW & $1.71 \mathrm{Aa}$ & $1.00 \mathrm{Bbc}$ & 1.20Bab & 1.30 & 3.11 & 2.80 & 2.73 & $2.88 \mathrm{bc}$ \\
\hline Means & 1.36 & 1.17 & 1.05 & & $3.33 \mathrm{~A}$ & $2.78 \mathrm{~B}$ & $2.68 \mathrm{~B}$ & \\
\hline C.V. (\%) & & 17.62 & & & & 15.20 & & \\
\hline
\end{tabular}

Means followed by the same letter, lowercase in the column for osmotic potentials and uppercase in the row for cultivars, do not differ from each other by Tukey test at 5\% probability level. Means without any letters did not differ significantly from each other by Tukey test at 5\% probability level. DIST - distilled water; PSW - public-supply water; WOS - water and oil separation; SAF - sand filter; SCF - sand + charcoal filter; SOF - sand + osmosis filter.

Table 7: Mean data of germination (GER), normal seedlings in the first count of the germination test (FC), deformed abnormal seedlings (DAS), non-germinated seeds (NGS), root length and hypocotyl length (RL and $\mathrm{HL}$ ) and root dry mass and hypocotyl dry mass (RDM and HDM) obtained from lettuce seeds, germinated in substrate moistened with solutions to simulate osmotic potentials relative to different types of produced water.

\begin{tabular}{|c|c|c|c|c|c|c|c|c|}
\hline \multirow{2}{*}{ Type of water } & GER & FC & DAS & NGS & $\mathrm{RL}$ & $\mathrm{HL}$ & RDM & HDM \\
\hline & \multicolumn{4}{|c|}{$(\%)$} & \multicolumn{2}{|c|}{$(\mathrm{cm})$} & \multicolumn{2}{|c|}{$\left(\mathrm{mg}\right.$ seedling $\left.{ }^{-1}\right)$} \\
\hline DIST & $82 a$ & $56 a$ & $10 c$ & $8 c$ & $1.6 a$ & $0.7 a$ & $0.19 a b$ & $0.21 a$ \\
\hline WOS & $40 c$ & Od & $29 a$ & $31 a$ & $0.0 c$ & $0.0 c$ & $0.00 c$ & $0.00 c$ \\
\hline SAF & $55 b$ & $28 \mathrm{c}$ & $20 a b$ & $25 a b$ & $1.8 \mathrm{a}$ & $0.5 a b$ & $0.11 a b c$ & $0.10 a b$ \\
\hline SCF & $55 b$ & $30 \mathrm{bc}$ & $25 a b$ & $20 a b$ & $1.6 a$ & $0.5 a b$ & $0.07 b c$ & $0.08 a b$ \\
\hline SOF & $62 \mathrm{~b}$ & $38 \mathrm{~b}$ & $25 a b$ & $13 b c$ & $1.5 a b$ & $0.5 a b$ & $0.22 \mathrm{a}$ & $0.20 a$ \\
\hline PSW & $63 b$ & $33 b c$ & $17 \mathrm{bc}$ & $20 a b$ & $1.3 b$ & $0.4 b$ & $0.13 a b$ & $0.10 a b$ \\
\hline C.V. (\%) & 7.35 & 12.63 & 12.41 & 11.06 & 6.53 & 12.79 & 2.6 & 3.45 \\
\hline
\end{tabular}

Means followed by the same letter, lowercase in the column for type of water, do not differ from each other by Tukey test at $5 \%$ probability level. DIST - distilled water; PSW - public-supply water; WOS - water and oil separation; SAF - sand filter; SCF - sand + charcoal filter; SOF - sand + osmosis filter. 
Table 8: Mean data of germination data (GER), normal seedlings at the first count of germination test (FC), deformed abnormal seedlings (DAS), non-germinated seeds (NGS), root length and hypocotyl length (RL and $\mathrm{HL}$ ) and root dry mass and hypocotyl dry mass (RDM and HDM) obtained from lettuce seeds germinated in substrate moistened with solutions to simulate osmotic potentials relative to different types of water.

\begin{tabular}{cllllllll}
\hline \multirow{2}{*}{ Type of water } & GER & FC & DAS & NGS & RL & HL & RDM & HDM \\
\cline { 2 - 9 } & \multicolumn{9}{c}{$(\%)$} & & & $(\mathrm{cm})$ & & \multicolumn{2}{c}{$\left(\mathrm{mg} \mathrm{seedling}^{-1}\right)$} \\
\hline DIST & $81 \mathrm{a}$ & $55 \mathrm{a}$ & $11 \mathrm{c}$ & $8 \mathrm{c}$ & $1.6 \mathrm{a}$ & $0.7 \mathrm{a}$ & $0.13 \mathrm{a}$ & $0.11 \mathrm{a}$ \\
WOS & $55 \mathrm{c}$ & $29 \mathrm{c}$ & $23 \mathrm{ab}$ & $23 \mathrm{a}$ & $1.5 \mathrm{a}$ & $0.6 \mathrm{ab}$ & $0.09 \mathrm{a}$ & $0.10 \mathrm{a}$ \\
SAF & $62 \mathrm{bc}$ & $35 \mathrm{bc}$ & $21 \mathrm{ab}$ & $17 \mathrm{ab}$ & $1.4 \mathrm{a}$ & $0.5 \mathrm{ab}$ & $0.09 \mathrm{a}$ & $0.10 \mathrm{a}$ \\
SCF & $63 \mathrm{bc}$ & $36 \mathrm{bc}$ & $26 \mathrm{a}$ & $12 \mathrm{ab}$ & $1.5 \mathrm{a}$ & $0.5 \mathrm{ab}$ & $0.10 \mathrm{a}$ & $0.05 \mathrm{~b}$ \\
SOF & $72 \mathrm{ab}$ & $51 \mathrm{a}$ & $19 \mathrm{abc}$ & $10 \mathrm{c}$ & $1.9 \mathrm{a}$ & $0.7 \mathrm{a}$ & $0.10 \mathrm{a}$ & $0.14 \mathrm{a}$ \\
PSW & $68 \mathrm{~b}$ & $41 \mathrm{~b}$ & $17 \mathrm{bc}$ & $15 \mathrm{ab}$ & $1.8 \mathrm{a}$ & $0.4 \mathrm{~b}$ & $0.15 \mathrm{a}$ & $0.16 \mathrm{a}$ \\
\hline C.V. (\%) & 7.76 & 9.23 & 9.18 & 18.20 & 7.85 & 10.29 & 5.61 & 12.10 \\
\hline
\end{tabular}

Means followed by the same letter, lowercase in the column for potentials, do not differ from each other by Tukey test at $5 \%$ probability level. DIST - distilled water; PSW - public-supply water; WOS - water and oil separation; SAF - sand filter; SCF - sand + charcoal filter; SOF - sand + osmosis filter.

In addition to the osmotic effect for produced water, the indication of toxicity reported in the present study reinforces the suggestion of Niemeyer et al. (2020), who evaluated the deleterious effects of the same waters on organisms that indicate ecotoxicity in soil and water. In this study with soil and aquatic organisms, the saline effect of the produced waters was identified and it was suggested that there must be a more toxic component, possibly related to hydrocarbons present, even after the treatments WOS, SAF and SCF, leaving only the SOF treatment as capable of removing toxicity both in this cited study and in the present study. In addition to salinity, some studies have shown that the water produced can be contaminated with boron and hydrocarbons, which represent important abiotic stresses (Miller et al., 2019; Ezechi et al., 2020).

In the present study, the $c v$. Catissol showed higher percentage of normal seedlings and higher seedling vigor (germination speed), regardless of the produced water used to moisten the substrate. Regardless of the cultivar, there was a trend of reduction in the germination and vigor of seedlings (root and hypocotyl length and hypocotyl dry mass) when using the produced water treated with WOS and SCF. Thus, it is suggested that under osmotic potentials representative of the different types of produced water, between -0.002 and $-0.1 \mathrm{MPa}$, there is no interference in the performance of sunflower seedlings only by water restriction.

In the verification of the possible water restriction of the substrate moistened with produced waters, it can be seen that the osmotic potentials reduced the germination and vigor of the seeds of the sunflower $c v$. Catissol, and the reduction of vigor evaluated by root length was more pronounced when using the produced water that passed through WOS, SAF and SCF systems. In sunflower, sensitivity to $\mathrm{NaCl}$ is known to vary between cultivars and crop development stage, however it is more inhibitory during the germination phase when compared to other stages (Mohammed; Benbella; Talouizete, 2002). Moreover, when the test was performed to verify or not the existence of the possible phytotoxicity of these waters, evaluated by the germination of lettuce seeds, it can be observed that the use of water from the WOS system reduced the percentage and speed of germination of lettuce seeds. All water potentials simulated by PEG solutions reduced the germination and vigor of lettuce seeds, and this reduction was more pronounced when using the water that passed through WOS.

Thus, further studies should be conducted to confirm the water restriction and toxicity of wastewater that passed through the WOS, SAF and SCF systems, as well as studies to adjust the methodology that employs seed germination and vigor tests as an alternative to elucidate physiological responses in the stage of plant performance in the field.

\section{CONCLUSION}

The reduction in germination and performance of sunflower seedlings of the cultivar Catissol may have been caused not only by the water restriction of the substrate, but also by possible toxicity, especially when the substrate was moistened with produced water that passed through 
the WOS, SAF and SCF systems, while the SOF system was considered adequate to detoxify the produced water.

\section{ACKNOWLEDGMENTS}

The authors thank the Petrobras Research Center for the technical and financial support.

\section{REFERENCES}

ADAM, G.; DUNCAN, H. Influence of diesel fuel on seed germination. Environmental Pollution, 120(2):363-370, 2002.

AHMADI, M.; SOURI, M. K. Growth characteristics and fruit quality of chili pepper under higher electrical conductivity of nutrient solution induced by various salts. AGRIVITA, Journal of Agricultural Science, 42(1):143-152, 2020.

ALBUQUERQUE, M. D. F.; CARVALHO, N. M. Effect of the type of environmental stress on the emergence of sunflower (Helianthus annus L.) soybean (Glicine max (L.) Merril) and maize (Zea mays L.) seeds with different levels of vigor. Seed Science and Technology, 31(2):465-479, 2003.

AL-GHOUTI, M. A. et al. Produced water characteristics, treatment and reuse: A review. Journal of Water Process Engineering, 28:222-239, 2019.

BRASIL. Ministério da Agricultura e Reforma Agrária. Regras para análise de sementes. Brasília: SNDA/DNDV/CLAV, 2009. 398p.

CHADHA, A. et al. Environmental factors affecting the germination and seedling emergence of two populations of an emerging agricultural weed: Wild lettuce (Lactuca serriola). Crop and Pasture Science, 70(8):709-717, 2019.

DOUSSEAU, S. et al. Ecofisiologia da germinação de sementes de Campomanesia pubescens. Ciência Rural, 41(8):13621368, 2011.

ECHCHELH, A.; HESS, T.; SAKRABANI, R. Reusing oil and gas produced water for irrigation of food crops in drylands. Agricultural Water Management, 206:124-134, 2018.

EZECHI, E. H. et al. A comparative evaluation of two electrode systems on continuous electrocoagulation of boron from produced water and mass transfer resistance. Journal of Water Process Engineering, 34:101133, 2020.

FRANZIN, S. M. et al. Métodos para avaliação do potencial fisiológico de sementes de alface. Revista Brasileira de Sementes, 26(2):63-69, 2004.
GUERRA, K.; DAHM, K.; DUNDORF, S. Oil and gas produced water management and beneficial use in the Western United States. Washington, DC: US Department of the Interior, Bureau of Reclamation, 2011. 113p.

HATAMIAN, M. et al. Growth characteristics of ornamental Judas tree (Cercis siliquastrum L.) seedling under different concentrations of lead and cadmium in irrigation water. Acta Scientiarum Polonorum Hortorum Cultus, 18(2):8796, 2019.

KAYA, M. D. et al. Seed treatments to overcome salt and drought stress during germination in sunflower (Helianthus annuus

L.). European Journal of Agronomy, 24(4):291-295, 2006.

KHALIQ, A. et al. Toxic action of aqueous wheat straw extract on horse purslane. Planta Daninha, 30(2):269-278, 2012.

LENZI, A. et al. Seed germination and seedling growth a mutant of sunflower (Helianthus annuus L.): Effect of abscisic acid and osmotic potential. Environmental and Experimental Botany, 35(4):427-434, 1995.

MARQUES, M. R. C. et al. Effects of untreated and treated oilfield-produced water on seed germination, seedling development, and biomass production of sunflower (Helianthus annuus L.). Environmental Science and Pollution Research, 22(20):15985-15993, 2015.

MASETTO, T. E.; RIBEIRO, D. M.; REZENDE, R. K. S. Germinação de sementes de Urochloa ruziziensis em função da disponibilidade hídrica do substrato e teor de água das sementes. Pesquisa Agropecuária Tropical, 43(4):385391, 2013.

MENESES, A. C. M. A. et al. Biological soil attributes in oilseed crops irrigated with oilfield produced water in the semi-arid region. Revista Ciência Agronômica, 48(2):231-241, 2017.

MICHEL, B. E.; KAUFMANN, M. R. The osmotic potential of polyethylene glycol 6000. Plant Physiology, 51(5):914916, 1973.

MILLER, H. et al. Food crop irrigation with oilfield-produced water suppresses plant immune response. Environmental Science \& Technology Letters, 6(11):656-661, 2019.

MOHAMMED, E. M.; BENBELLA, M.; TALOUIZETE, A. effect of sodium chloride on sunflower (Helianthus annuus L.) seed germination. Helia, 25(37):51-58, 2002.

MOTTA, A. R. P. et al. Tratamento de água produzida de petróleo para remoção de óleo por processos de separação por membranas: Revisão. Engenharia Sanitária e Ambiental, 18(1):15-26, 2013. 
NAKAGAWA, J. Testes de vigor baseados na avaliação das plântulas. In: KRZYZANOWSKI, F. C. et al. Vigor de sementes: Conceitos e testes. Londrina: ABRATES, p.2.1-2.21, 1999.

NIEMEYER, J. C. et al. Treated produced water in irrigation: Effects on soil fauna and aquatic organisms. Chemosphere, 240(2):124791, 2020.

NOBRE, D. A. C. et al. Vigor and viability sunflower achenes as determined by the tetrazolium test. Pesquisa Agropecuária Pernambucana, 19(2):89-93, 2014.

NOBRE, R. G. et al. Crescimento e floração do girassol sob estresse salino e adubação nitrogenada. Revista Ciência Agronômica, 41(3):358-365, 2010.

OLIVEIRA, M. L. A. et al. Crescimento e produção de girassol ornamental irrigado com diferentes lâminas e diluições de água residuária. Irriga, 22(2):204-219, 2017.

RABBANI, A. R. C. et al. Efeito do estresse salino sobre atributos da germinação de sementes de girassol. Scientia Plena, 9(5):1-6, 2013.
SAUX, M. et al. A Correlative study of sunflower seed vigor components as related to genetic background. Plants, 9(3):386, 2020.

SOURI, M. K.; HATAMIAN, M. Aminochelates in plant nutrition: A review. Journal of Plant Nutrition, 42(1):67-78, 2019.

SOUSA, A. F. et al. Nutrient content in sunflowers irrigated with oil exploration water. Revista Caatinga, 29(1):94100, 2016.

TARSITANO, R. A. et al. Custos e rentabilidade da produção de girassol no estado do Mato Grosso, Brasil. Revista ESPACIOS, 37(12):26-35, 2016.

ZIMMERMANN, F. J. P. Estatística aplicada à pesquisa agrícola. Santo Antônio de Goiás: Embrapa Arroz e Feijão, 2004. 402p.

ZOBIOLE, L. H. S. et al. Marcha de absorção de macronutrientes na cultura do girassol. Revista Brasileira de Ciência do Solo, 34(2):425-433, 2010. 